\title{
Bacillus luteolus sp. nov., a halotolerant bacterium isolated from a salt field
}

\author{
Rong Shi, ${ }^{1} \dagger$ Min Yin, ${ }^{1} \dagger$ Shu-Kun Tang, ${ }^{1}$ Jae-Chan Lee, ${ }^{2}$ Dong-Jin Park, ${ }^{2}$ \\ Yun-Jiao Zhang, ${ }^{1}$ Chang-Jin $\mathrm{Kim}^{2}$ and Wen-Jun $\mathrm{Li}^{1}$ \\ ${ }^{1}$ The Key Laboratory for Microbial Resources of the Ministry of Education, PR China, and \\ Laboratory for Conservation and Utilization of Bio-Resources, Yunnan Institute of Microbiology, \\ Yunnan University, Kunming, 650091, PR China \\ ${ }^{2}$ Functional Metabolite Research Center, KRIBB, 52 Eoeun-dong, Yuseong gu, Daejeon 305-806, \\ Republic of Korea
}

\author{
Correspondence \\ Wen-Jun Li \\ wjli@ynu.edu.cn \\ Chang-Jin Kim \\ changjin@kribb.re.kr
}

Since the genus Bacillus was first described by Cohn in 1872, the number of Bacillus species has increased considerably. It is one of the largest bacterial genera, including more than 200 species (Euzéby, 2010). Many Bacillus species are aerobic, spore-forming, halophilic or halotolerant, Gram-positive rods. The genus is considered to be ubiquitous, because Bacillus species have been isolated from a wide variety of aquatic and terrestrial environments, such as dust (Venkateswaran et al., 2003), river-mouth sediments (Ruiz-García et al., 2005), sandy soil (Lee et al., 2008) and hypersaline lakes (Amoozegar et al., 2009). During an investigation of the culturable bacterial community in sediments from a salt field in South Korea, a large number of bacterial strains were isolated. In

†These authors contributed equally to this work.

Abbreviation: m-Dpm, meso-diaminopimelic acid.

The GenBank/EMBL/DDBJ accession number for the 16S rRNA gene sequence of strain YIM $93174^{\top}$ is G0925365.

Four supplementary figures and a supplementary table are available with the online version of this paper. this study, we characterized a new isolate, designated YIM $93174^{\mathrm{T}}$. Based on the results of a polyphasic study conducted according to the minimal standards for describing new taxa of aerobic, endospore-forming bacteria (Logan et al., 2009), strain YIM $93174^{\mathrm{T}}$ is proposed to represent a novel species of the genus Bacillus.

Strain YIM $93174^{\mathrm{T}}$ was isolated from a salt field in Mokpo city, South Korea. For isolation, serial dilutions of the sample were spread on glucose-tryptone-yeast extract (GTY) medium (containing $5 \% \mathrm{NaCl}$ ), described by Tang et al. (2010), and incubated at $37^{\circ} \mathrm{C}$ for 3 weeks. Colonies were picked and restreaked repeatedly onto GTY medium until purity was confirmed. Strain YIM $93174^{\mathrm{T}}$ was maintained on GTY agar slants at $4{ }^{\circ} \mathrm{C}$ and in $25 \%$ $(\mathrm{v} / \mathrm{v})$ glycerol suspensions at $-80{ }^{\circ} \mathrm{C}$. Biomass for chemical and molecular studies was obtained by cultivation in shake flasks (about 150 r.p.m.) using GTY broth $(2 \% \mathrm{NaCl}$, $\mathrm{pH}$ 7.0) at $37^{\circ} \mathrm{C}$ for about a week.

Genomic DNA was extracted and purified according to the method described by Li et al. (2007). The 16S rRNA gene 
was amplified by PCR using primers 8-27f and 1523-1504r (Cui et al., 2001) and PCR products were purified using a PCR purification kit (Sangon). The purified PCR product was sequenced directly on an ABI model 3730 automatic DNA sequencer by using a PRISM ready reaction dye primer cycle sequencing kit. The resulting sequence data were analysed with the BLASTN program of GenBank. Sequences were aligned using the CLUSTAL_X software (Thompson et al., 1997) and the alignment was corrected manually. Phylogenetic analyses were performed using three tree-making algorithms, the neighbour-joining (Saitou \& Nei, 1987), maximum-likelihood (Felsenstein, 1981) and maximum-parsimony (Fitch, 1971) methods. A phylogenetic tree was reconstructed using the neighbourjoining method of Saitou \& Nei (1987) from $K_{\text {nuc }}$ values (Kimura, 1980) using MEGA version 4.0 (Tamura et al., 2007). The topology of the phylogenetic tree was evaluated by the bootstrap resampling method with 1000 replicates (Felsenstein, 1985). The genomic DNA G $+C$ content was determined by the method of Mesbah et al. (1989) using DNA prepared according to Marmur (1961); DNA from Escherichia coli JM 109 was used as a control.

An almost-complete 16S rRNA gene sequence (1486 bp) of strain YIM $93174^{\mathrm{T}}$ was obtained. Fig. 1 shows the relationship of the novel strain and its nearest phylogenetic relatives, based on a neighbour-joining analysis of $16 \mathrm{~S}$ rRNA gene sequences. The results of $16 \mathrm{~S}$ rRNA gene sequence comparison clearly demonstrated that strain YIM $93174^{\mathrm{T}}$ was a member of the genus Bacillus and formed a distinct subclade with Bacillus humi LMG 22167 ${ }^{\mathrm{T}}$, Bacillus litoralis $\mathrm{SW}-211^{\mathrm{T}}$ and Bacillus alkalitelluris $\mathrm{BA} 288^{\mathrm{T}}$. The
16S rRNA gene sequence similarity between strain YIM $93174^{\mathrm{T}}$ and its closest neighbours, B. humi LMG $22167^{\mathrm{T}}$, B. litoralis $\mathrm{SW}-211^{\mathrm{T}}$ and B. alkalitelluris $\mathrm{BA} 288^{\mathrm{T}}$, was 95.7 , 94.9 and $94.5 \%$, respectively. Topologies of phylogenetic trees built using the maximum-likelihood and maximumparsimony algorithms were similar to that of the tree constructed by neighbour-joining analysis (Fig. 1 and Supplementary Figs S1 and S2, available in IJSEM Online). The genomic DNA G + C content of strain YIM $93174^{\mathrm{T}}$ was $36.9 \mathrm{~mol} \%$.

Cell morphology was determined using cultures grown for $6,12,24,48$ and $72 \mathrm{~h}$ on GTY agar medium supplemented with $2 \%(\mathrm{w} / \mathrm{v}) \mathrm{NaCl}$ at $37{ }^{\circ} \mathrm{C}$ and examined by transmission electron microscopy (H-800; Hitachi). Gram staining was carried out by the standard Gram reaction combined with the KOH lysis test (Cerny, 1978). MSM medium (Vaishampayan et al., 2009) supplemented with $2 \% \mathrm{NaCl}$ was used to induce sporulation at $37{ }^{\circ} \mathrm{C}$ for $24 \mathrm{~h}$ and purified spores were detected by using malachite green staining (Smibert \& Krieg, 1994). Cell motility was detected by the presence of turbidity throughout tubes containing semisolid medium (Leifson, 1960). Methyl red and VogesProskauer tests were performed as described previously (Smibert \& Krieg, 1981). The temperature range for growth was determined by incubating cells for a week on GTY medium at $5-55{ }^{\circ} \mathrm{C}$ (at intervals of $5{ }^{\circ} \mathrm{C}$ ). Growth was investigated at $\mathrm{pH} 4.0-10.0$, at intervals of $1 \mathrm{pH}$ unit, using the buffer system described by Xu et al. (2005). Growth in $0-20 \%(\mathrm{w} / \mathrm{v}) \mathrm{NaCl}$, at intervals of $1 \%$, was tested by using ISP 4 medium as the basal medium. B. humi DSM $16318^{\mathrm{T}}$, B. litoralis DSM $16303^{\mathrm{T}}$ and B. alkalitelluris DSM $16976^{\mathrm{T}}$

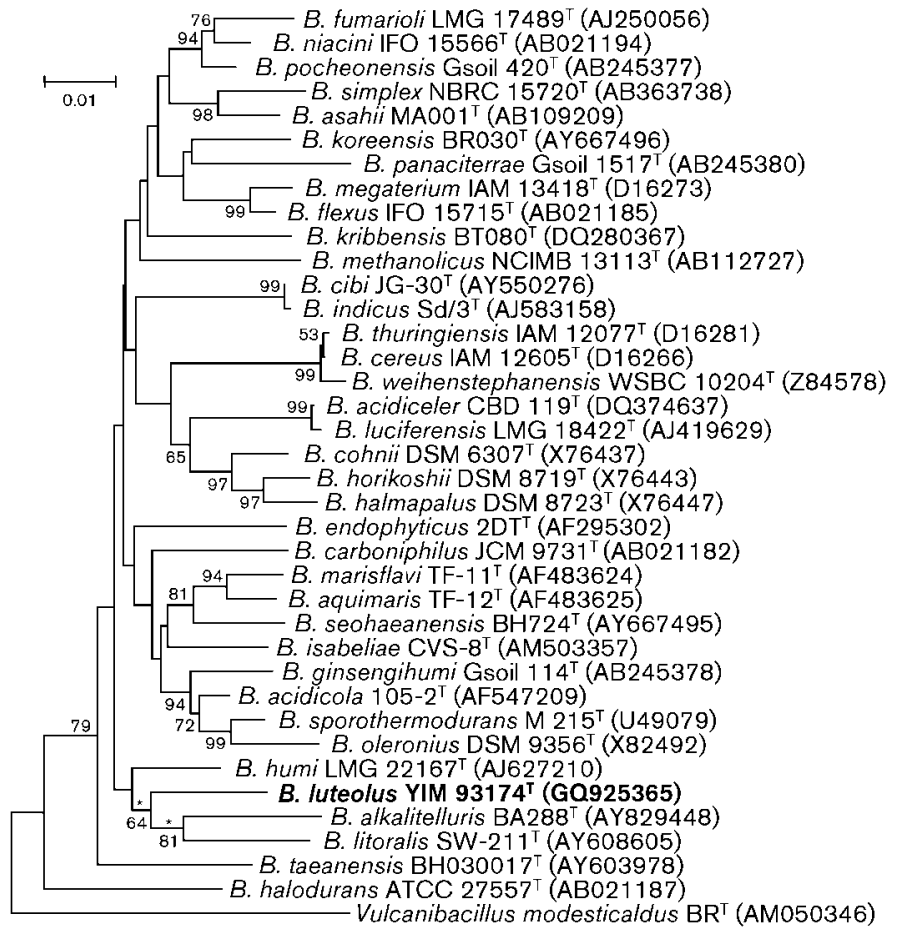

Fig. 1. Phylogenetic tree based on $16 \mathrm{~S}$ rRNA gene sequence analysis, reconstructed using the neighbour-joining method (Saitou \& Nei, 1987), showing the interrelationship of strain YIM $93174^{\top}$ and members of closely related species. Asterisks indicate branches that were also found using the maximum-likelihood (Felsenstein, 1981) and maximum-parsimony (Fitch, 1971) tree-making algorithms (Supplementary Figs S1 and S2). Numbers at branching points refer to bootstrap values (percentages of 1000 resamplings; only values above $50 \%$ are shown). The sequence of Vulcanibacillus modesticaldus $\mathrm{BR}^{\top}$ was used as an outgroup. Bar, $1 \%$ sequence divergence. 
were used as reference strains for physiological and biochemical characteristics tests and they were obtained from the Deutsche Sammlung von Mikroorganismen und Zellkulturen GmbH (DSMZ). Catalase activity was determined by production of bubbles after addition of a drop of $3 \% \mathrm{H}_{2} \mathrm{O}_{2}$. Oxidase activity was observed by oxidation of tetramethyl- $p$-phenylenediamine. Hydrolysis of aesculin, dextrin, casein, gelatin, starch, urea and Tweens 20, 40, 60 and 80 was determined as described by Cowan \& Steel (1965). Enzyme activity and acid production tests were carried out using the API 50CHB, API 20E and API ZYM systems (bioMérieux) according to the manufacturer's instructions. Utilization of different compounds as sole carbon or nitrogen and energy sources was tested as described by Carrasco et al. (2006). Antibiotic susceptibility was determined by the method of Williams (1967). Anaerobic growth was determined using the GasPak Anaerobic System (BBL) according to the manufacturer's instructions.

The morphological characteristics of strain YIM $93174^{\mathrm{T}}$ were distinctly different from those of $B$. humi DSM $16318^{\mathrm{T}}$, B. litoralis DSM $16303^{\mathrm{T}}$ and B. alkalitelluris DSM $16976^{\mathrm{T}}$ (Table 1). The detailed physiological and biochemical characteristics of the strain are given in the species description.

Peptidoglycan was purified and cell-wall amino acids and peptides in cell-wall hydrolysates were analysed by twodimensional ascending TLC on cellulose plates using the solvent systems of Schleifer \& Kandler (1972). For fatty acid analysis, cells of strain YIM $93174^{\mathrm{T}}$ was cultured on tryptic soy agar (TSA; BD) containing $2 \% \mathrm{NaCl}$ at $37^{\circ} \mathrm{C}$ with shaking for $48 \mathrm{~h}$. Analysis of cellular fatty acids was performed as described by Sasser (1990) using the Microbial Identification System (MIDI, Inc.). Menaquinones were isolated using the methods of Minnikin et al. (1984) and separated by HPLC (Kroppenstedt, 1982). Polar lipids were extracted, examined by two-dimensional TLC and identified using published procedures (Minnikin et al., 1984). The peptidoglycan contained meso-diaminopimelic acid ( $m$-Dpm), which is characteristic of the genus Bacillus [peptidoglycan type A1 $\gamma$ ( $m$-Dpm direct, type A31); DSMZ, 2004]. The predominant menaquinone of the isolate was MK-7. Strain YIM $93174^{\mathrm{T}}$ had a cellular fatty acid profile that contained major amounts of branched fatty acids and minor amounts of straight-chain and unsaturated fatty acids; the major cellular fatty acids were iso- $\mathrm{C}_{15: 0}(46.2 \%)$, anteiso- $\mathrm{C}_{15: 0}(17.1 \%)$ and iso- $\mathrm{C}_{16: 0}(13.7 \%)$. The polar lipids of strain YIM $93174^{\mathrm{T}}$ consisted of diphosphatidylglycerol, phosphatidylglycerol, phosphatidylethanolamine, phosphatidylinositol, phosphatidylinositol mannoside and two unknown phospholipids (Supplementary Fig. S3). The chemotaxonomic properties of strain YIM $93174^{\mathrm{T}}[\mathrm{A} 1 \gamma(\mathrm{m}$ Dpm direct, type A31) as peptidoglycan type; iso- $\mathrm{C}_{15: 0}$, anteiso- $\mathrm{C}_{15: 0}$ and iso- $\mathrm{C}_{16: 0}$ as major fatty acids; MK-7 as predominant menaquinone] are similar to those of $B$. humi DSM $16318^{\mathrm{T}}$, B. litoralis DSM $16303^{\mathrm{T}}$ and B. alkalitelluris DSM $16976^{\mathrm{T}}$ (Heyrman et al., 2005; Yoon \& Oh, 2005; Lee et al., 2008). However, strain YIM $93174^{\mathrm{T}}$ exhibited some differences from B. humi DSM $16318^{\mathrm{T}}$, B. litoralis DSM $16303^{\mathrm{T}}$ and B. alkalitelluris DSM $16976^{\mathrm{T}}$ in their fatty acid compositions (Supplementary Table S1), which were determined under the same laboratory conditions.

Thus, based on phenotypic (Table 1 and Supplementary Table S1) and phylogenetic (Fig. 1) differences between the novel strain and previously described species within the genus Bacillus, we consider that strain YIM $93174^{\mathrm{T}}$ represents a novel species, for which we propose the name Bacillus luteolus sp. nov.

\section{Description of Bacillus luteolus sp. nov.}

Bacillus luteolus (lu.te.o'lus. L. masc. adj. luteolus yellowish, pale tangerine-coloured).

Cells are Gram-stain-positive, strictly aerobic, thin rods, $0.7-0.9 \times 2.0-5.0 \mu \mathrm{m}$, motile by means of peritrichous flagella (Supplementary Fig. S4). Spherical endospores are produced in a terminal position. Colonies are $0.5-2 \mathrm{~mm}$ in diameter, circular, pale tangerine in colour, convex and opaque on GTY medium. Grows at $0-10 \%(w / v) \mathrm{NaCl}$, with optimal growth at $0-2 \%(\mathrm{w} / \mathrm{v}) \mathrm{NaCl}$. Growth occurs at $15-45{ }^{\circ} \mathrm{C}$ and at $\mathrm{pH} 6.0-8.0$, with optimal growth at 28 $37^{\circ} \mathrm{C}$ and $\mathrm{pH}$ 7.0. Nitrate is not reduced to nitrite under anaerobic or aerobic conditions. Catalase is detected. Oxidase, methyl red and Voges-Proskauer tests are negative. Indole and $\mathrm{H}_{2} \mathrm{~S}$ are not produced. Dextrin and Tweens 20, 40 and 60 are hydrolysed, but casein, gelatin, starch, Tween 80 and aesculin are not hydrolysed. Acids are produced from potassium 5-ketogluconate (weakly), D-fructose, sucrose, turanose, D-xylose, glycerol (weakly) and glycogen (weakly), but not from L-arabinose, D-ribose, L-xylose, D-galactose, D-glucose, D-mannose, L-rhamnose, myo-inositol, D-mannitol, D-sorbitol, cellobiose, maltose, melibiose, trehalose, melezitose or raffinose (API 50CHB). In the API 20E system, positive for arginine dihydrolase and urease, but negative for $o$-nitrophenyl $\beta$-D-galactoside hydrolysis, lysine decarboxylase, ornithine decarboxylase and tryptophan deaminase. In the API ZYM system, tests for alkaline phosphatase, esterase (C4), esterase lipase (C8), lipase (C14), leucine arylamidase, naphthol-AS-BI-phosphohydrolase and $\alpha$-glucosidase are positive, but valine arylamidase, cystine arylamidase, trypsin, $\alpha$-chymotrypsin, acid phosphatase, $\alpha$-galactosidase, $\beta$-galactosidase, $\beta$-glucuronidase, $\beta$-glucosidase, $N$-acetyl- $\beta$-glucosaminidase, $\alpha$ mannosidase, $\alpha$-fucosidase, lysine decarboxylase and ornithine decarboxylase tests are negative. The following compounds are utilized as sole carbon or nitrogen sources: L-arginine, hypoxanthine, sodium citrate, lactose, L-rhamnose, D-xylose, D-ribose and glycerol. Susceptible to ( $\mu \mathrm{g}$ per disc unless indicated) amikacin (30), ampicillin (10), ciprofloxacin (5), clindamycin (2), erythromycin (15), gentamicin (10), novobiocin (30), streptomycin (10), tobramycin (10), vancomycin (30), amoxicillin (10), chloramphenicol (30), netilmicin sulfate (30), norfloxacin (10), penicillin (10 U), rifampicin (5), trimethoprim 
Table 1. Characteristics that differentiate strain YIM $93174^{\top}$ from the type strains of closely related species

Strains: 1, YIM 93174 ${ }^{\mathrm{T}}$; 2, B. humi DSM $16318^{\mathrm{T}}$; 3, B. alkalitelluris DSM 16976 ${ }^{\mathrm{T}}$; 4, B. litoralis DSM $16303^{\mathrm{T}}$. +, Positive; -, negative; w, weakly positive; ND, no data available. Data were obtained in this study unless indicated. All strains are Gram-positive, motile rods. All strains tested negative for hydrolysis of starch, chitin and cellulose (this study). In the API ZYM system (this study), all strains were positive for alkaline phosphatase, esterase (C4), esterase lipase (C8) and naphthol-AS-BI-phosphohydrolase and negative for $\alpha$-galactosidase, $N$-acetyl- $\beta$ glucosaminidase, $\alpha$-mannosidase and $\alpha$-fucosidase. In the API 50CHB system (this study), acids were not produced by any of the strains from erythritol, D-arabinose, L-xylose, D-adonitol, methyl $\beta$-D-xylopyranoside, D-mannose, L-sorbose, L-rhamnose, dulcitol, inositol, D-sorbitol, methyl $\alpha$-D-mannopyranoside, arbutin, inulin, xylitol, D-lyxose, D-tagatose, D- or L-fucose, D- or L-arabitol, potassium gluconate or potassium 2-ketogluconate.

\begin{tabular}{|c|c|c|c|c|}
\hline Characteristic & 1 & 2 & 3 & 4 \\
\hline Colony colour ${ }^{*}$ & PT & $\mathrm{WH}^{a_{\dagger}}$ & $\mathrm{CR}^{b}$ & $\mathrm{YW}^{c}$ \\
\hline Spore shape $\ddagger$ & s & $\mathrm{E} / \mathrm{s}^{a}$ & $\mathrm{E}^{b}$ & $\mathrm{E}^{c}$ \\
\hline \multicolumn{5}{|c|}{ Temperature for growth $\left({ }^{\circ} \mathrm{C}\right)$} \\
\hline Range & $15-45$ & $20-40^{a}$ & $15-40^{b}$ & $4-45^{c}$ \\
\hline Optimum & $28-37$ & $30^{a}$ & $30^{b}$ & $37^{c}$ \\
\hline Range & $6.0-8.0$ & $6.0-9.0^{a}$ & $7.0-11.0^{b}$ & $\geqslant 5.5^{c}$ \\
\hline Optimum & 7.0 & ND & $9.0-9.5^{b}$ & $7.5^{c}$ \\
\hline \multicolumn{5}{|c|}{$\mathrm{NaCl}$ concentration for growth $(\%, \mathrm{w} / \mathrm{v})$} \\
\hline Range & $0-10$ & ND & $0-4^{b}$ & $0-10^{c}$ \\
\hline Optimum & $0-2$ & $7^{a}$ & $0-1^{b}$ & $2-3^{c}$ \\
\hline Anaerobic growth & - & $\mathrm{w}^{a}$ & $+{ }^{b}$ & $-^{c}$ \\
\hline Aesculin & - & + & + & + \\
\hline Casein & - & - & - & + \\
\hline Dextrin & + & - & - & + \\
\hline Tween 20 & + & + & - & - \\
\hline Tween 40 & + & - & - & + \\
\hline Tween 60 & + & + & - & + \\
\hline Urea & + & + & - & - \\
\hline \multicolumn{5}{|c|}{ Enzymic activity (API ZYM) } \\
\hline Acid phosphatase & - & + & - & + \\
\hline$\alpha$-Chymotrypsin & - & + & + & + \\
\hline Cystine arylamidase & - & + & + & - \\
\hline Valine arylamidase & - & + & + & - \\
\hline \multicolumn{5}{|c|}{ Acid production from (API $50 \mathrm{CH}$ ): } \\
\hline $\mathrm{N}$-Acetylglucosamine & - & - & - & + \\
\hline Aesculin & - & - & + & + \\
\hline Amygdalin & - & - & - & + \\
\hline L-Arabinose & - & - & + & + \\
\hline Cellobiose & - & - & + & + \\
\hline D-Fructose & + & - & - & + \\
\hline Galactose & - & - & - & + \\
\hline Glucose & - & - & - & + \\
\hline Glycogen & + & - & - & + \\
\hline Glycerol & + & - & - & + \\
\hline
\end{tabular}


Table 1. cont.

\begin{tabular}{|c|c|c|c|c|}
\hline Characteristic & 1 & 2 & 3 & 4 \\
\hline D-Mannitol & - & - & + & + \\
\hline Maltose & - & - & + & + \\
\hline Potassium 5-ketogluconate & + & + & + & - \\
\hline Raffinose & - & - & - & + \\
\hline Salicin & - & - & + & + \\
\hline Starch & + & - & - & + \\
\hline Sucrose & + & - & + & + \\
\hline Trehalose & - & - & + & + \\
\hline Turanose & + & - & - & + \\
\hline D-Xylose & + & - & + & + \\
\hline DNA G $+C$ content $(\mathrm{mol} \%)$ & 36.9 & $37.5^{a}$ & $37.9^{b}$ & $35.2^{c}$ \\
\hline
\end{tabular}

${ }^{*} \mathrm{CR}$, Creamy; PT, pale tangerine; WH, whitish; Yw, yellowish white.

$\dagger$ Data taken from: $a$, Heyrman et al. (2005); b, Lee et al. (2008); c, Yoon \& Oh (2005).

‡E, Ellipsoidal; s, spherical.

§C, Central or paracentral; ST, subterminal; T, terminal.

sulfonamide (1.25) and tetracycline (30). The cell-wall peptidoglycan is of the Al $\gamma$ type, containing $m$-Dpm as the diagnostic diamino acid. The predominant isoprenoid quinone is MK-7. The polar lipid pattern consists of diphosphatidylglycerol, phosphatidylglycerol, phosphatidylethanolamine, phosphatidylinositol, phosphatidylinositol mannoside and two unknown phospholipids. The major cellular fatty acids are iso- $\mathrm{C}_{15: 0}$, anteiso- $\mathrm{C}_{15: 0}$ and iso- $\mathrm{C}_{16: 0}$. The $\mathrm{G}+\mathrm{C}$ content of the DNA of the type strain is $36.9 \mathrm{~mol} \%$.

The type strain is YIM $93174^{\mathrm{T}}\left(=\mathrm{DSM} 22388^{\mathrm{T}}=\right.$ KCTC $13210^{\mathrm{T}}=$ CCTCC AA $208068^{\mathrm{T}}$ ), isolated from a salt field in Korea.

\section{Acknowledgements}

The authors are grateful to Professor Hans-Peter Klenk for kindly providing the reference type strains. This research was supported by the National Basic Research Program of China (no. 2010CB833800) and the 21C Frontier Program of Microbial Genomics and Applications from the MEST, Korea.

\section{References}

Amoozegar, M. A., Sánchez-Porro, C., Rohban, R., Hajighasemi, M. \& Ventosa, A. (2009). Bacillus persepolensis sp. nov., a moderately halophilic bacterium from a hypersaline lake. Int J Syst Evol Microbiol 59, 2352-2358.

Carrasco, I. J., Márquez, M. C., Yanfen, X., Ma, Y., Cowan, D. A., Jones, B. E., Grant, W. D. \& Ventosa, A. (2006). Gracilibacillus orientalis sp. nov., a novel moderately halophilic bacterium isolated from a salt lake in Inner Mongolia, China. Int J Syst Evol Microbiol 56, 599-604.

Cerny, G. (1978). Studies on aminopeptidase for the distinction of Gram-negative from Gram-positive bacteria. Eur J Appl Microbiol Biotechnol 5, 113-122.

Cowan, S. T. \& Steel, K. J. (1965). Manual for the Identification of Medical Bacteria. London: Cambridge University Press.
Cui, X. L., Mao, P. H., Zeng, M., Li, W. J., Zhang, L. P., Xu, L. H. \& Jiang, C. L. (2001). Streptimonospora salina gen. nov., sp. nov., a new member of the family Nocardiopsaceae. Int J Syst Evol Microbiol 51, 357-363.

DSMZ (2004). Key to murein (peptidoglycan) types. Braunschweig: Deutsche Sammlung von Mikroorganismen und Zellkulturen. http:// www.dsmz.de/microorganisms/main.php?content_id=35

Euzéby, J. P. (2010). Bacillus Cohn 1872, genus. In List of Prokaryotic Names with Standing in Nomenclature. http://www.bacterio.cict.fr/b/ bacillus.html

Felsenstein, J. (1981). Evolutionary trees from DNA sequences: a maximum likelihood approach. J Mol Evol 17, 368-376.

Felsenstein, J. (1985). Conference limits on phylogenies: an approach using the bootstrap. Evolution 39, 783-791.

Fitch, W. M. (1971). Toward defining the course of evolution: minimum change for a specific tree topology. Syst Zool 20, 406416.

Heyrman, J., Rodríguez-Díaz, M., Devos, J., Felske, A., Logan, N. A. \& De Vos, P. (2005). Bacillus arenosi sp. nov., Bacillus arvi sp. nov. and Bacillus humi sp. nov., isolated from soil. Int J Syst Evol Microbiol 55, 111-117.

Kimura, M. (1980). A simple method for estimating evolutionary rates of base substitutions through comparative studies of nucleotide sequences. J Mol Evol 16, 111-120.

Kroppenstedt, R. M. (1982). Separation of bacterial menaquinones by HPLC using reverse phase (RP 18) and a silver loaded ion exchanger as stationary phases. J Liq Chromatogr 5, 2359-2367.

Lee, J. C., Lee, G. S., Park, D. J. \& Kim, C. J. (2008). Bacillus alkalitelluris sp. nov., an alkaliphilic bacterium isolated from sandy soil. Int J Syst Evol Microbiol 58, 2629-2634.

Leifson, E. (1960). Atlas of Bacterial Flagellation. London: Academic Press.

Li, W. J., Xu, P., Schumann, P., Zhang, Y.-Q., Pukall, R., Xu, L.-H., Stackebrandt, E. \& Jiang, C. L. (2007). Georgenia ruanii sp. nov., a novel actinobacterium isolated from forest soil in Yunnan (China), and emended description of the genus Georgenia. Int J Syst Evol Microbiol 57, 1424-1428.

Logan, N. A., Berge, O., Bishop, A. H., Busse, H. J., De Vos, P., Fritze, D., Heyndrickx, M., Kämpfer, P., Rabinovitch, L. \& other authors (2009). 
Proposed minimal standards for describing new taxa of aerobic, endospore-forming bacteria. Int J Syst Evol Microbiol 59, 2114-2121.

Marmur, J. (1961). A procedure for the isolation of deoxyribonucleic acid from microorganisms. J Mol Biol 3, 208-218.

Mesbah, M., Premachandran, U. \& Whitman, W. B. (1989). Precise measurement of the $\mathrm{G}+\mathrm{C}$ content of deoxyribonucleic acid by highperformance liquid chromatography. Int J Syst Bacteriol 39, 159-167.

Minnikin, D. E., O'Donnell, A. G., Goodfellow, M., Alderson, G., Athalye, M., Schaal, A. \& Parlett, J. H. (1984). An integrated procedure for the extraction of bacterial isoprenoid quinones and polar lipids. J Microbiol Methods 2, 233-241.

Ruiz-García, C., Quesada, E., Martínez-Checa, F., Llamas, I., Urdaci, M. C. \& Béjar, V. (2005). Bacillus axarquiensis sp. nov. and Bacillus malacitensis sp. nov., isolated from river-mouth sediments in southern Spain. Int J Syst Evol Microbiol 55, 1279-1285.

Saitou, N. \& Nei, M. (1987). The neighbor-joining method: a new method for reconstructing phylogenetic trees. Mol Biol Evol 4, 406425.

Sasser, M. (1990). Identification of bacteria by gas chromatography of cellular fatty acids. USFCC Newsl 20, 16.

Schleifer, K. H. \& Kandler, O. (1972). Peptidoglycan types of bacterial cell walls and their taxonomic implications. Bacteriol Rev 36, 407-477.

Smibert, R. M. \& Krieg, N. R. (1981). General characterization. In Manual of Methods for General Bacteriology, pp. 409-443. Edited by P. Gerhardt, R. G. E. Murray, R. N. Costilow, E. W. Nester, W. A. Wood, N. R. Krieg \& G. B. Philips. Washington, DC: American Society for Microbiology.

Smibert, R. M. \& Krieg, N. R. (1994). Phenotypic characterization. In Methods for General and Molecular Bacteriology, pp. 607-654. Edited by P. Gerhardt, R. G. E. Murray, W. A. Wood \& N. R. Krieg. Washington, DC: American Society for Microbiology.

Tamura, K., Dudley, J., Nei, M. \& Kumar, S. (2007). MEGA4: molecular evolutionary genetics analysis (MEGA) software version 4.0. Mol Biol Evol 24, 1596-1599.

Tang, S. K., Wang, Y., Lee, J. C., Lou, K., Park, D. J., Kim, C. J. \& Li, W. J. (2010). Georgenia halophila sp. nov., a halophilic actinobacterium isolated from a salt lake. Int J Syst Evol Microbiol 60, 1317-1421.

Thompson, J. D., Gibson, T. J., Plewniak, F., Jeanmougin, F. \& Higgins, D. G. (1997). The CLUSTAL_X windows interface: flexible strategies for multiple sequence alignment aided by quality analysis tools. Nucleic Acids Res 25, 4876-4882.

Vaishampayan, P., Miyashita, M., Ohnishi, A., Satomi, M., Rooney, A., La Duc, M. T. \& Venkateswaran, K. (2009). Description of Rummeliibacillus stabekisii gen. nov., sp. nov. and reclassification of Bacillus pycnus Nakamura et al. 2002 as Rummeliibacillus pycnus comb. nov. Int J Syst Evol Microbiol 59, 1094-1099.

Venkateswaran, K., Kempf, M., Chen, F., Satomi, M., Nicholson, W. \& Kern, R. (2003). Bacillus nealsonii sp. nov., isolated from a spacecraftassembly facility, whose spores are gamma-radiation resistant. Int J Syst Evol Microbiol 53, 165-172.

Williams, S. T. (1967). Sensitivity of streptomycetes to antibiotics as a taxonomic character. J Gen Microbiol 46, 151-160.

Xu, P., Li, W. J., Tang, S. K., Zhang, Y. Q., Chen, G. Z., Chen, H. H., Xu, L. H. \& Jiang, C. L. (2005). Naxibacter alkalitolerans gen. nov., sp. nov., a novel member of the family 'Oxalobacteraceae' isolated from China. Int J Syst Evol Microbiol 55, 1149-1153.

Yoon, J.-H. \& Oh, T. K. (2005). Bacillus litoralis sp. nov., isolated from a tidal flat of the Yellow Sea in Korea. Int J Syst Evol Microbiol 55, 1945-1948. 